INTERNATIONAL HIGHER EDUCATION NO. 69 FALL 2012

The Role of Regulating Private For-profit Higher Education

WILLIAM G. TIERNEY

William G. Tierney is professor and director of the Center for Higher Education Policy Analysis, Rossier School of Education, at the University of Southern California, Los Angeles. E-mail: wgtiern@usc.edu.

Although private nonprofit colleges and universities have a long and distinguished history throughout the world, what has come to be known as "forprofit higher education" is a relative newcomer. Private nonprofit institutions, such as Stanford University in the United States or Universidad Santa Maria la Antigua in Panama, are examples of established universities with significant reputations. Their focus and intent has been relatively clear. They are largely mission focused or cater to a specific traditionally aged clientele, such as members of a particular religion.

For-profit higher education is a relative newcomer onto the world stage, even though the prototype has existed for quite some time. Small, technical training institutions came into existence in the 19th century, as a way to give individuals a vocation. Barbers, plumbers, secretaries, and a host of other trades are engaged in the sorts of professions taught at relatively small postsecondary institutions. The owners of these institutions generally did not think of themselves as competitors to either public or private tertiary institutions. Instead, 
these schools taught a trade to working-class students and turned a modest profit.

Over time, the institutions became a bit more formalized. Trades became professions, and in order to be licensed by the state the student may have needed to pass an exam or amass a specific number of credits. The state may have required that all of the students who were to be licensed also needed a high school degree or its equivalent. The result was that the small for-profit institution may have added courses that enabled students to gain their high school equivalency. Nevertheless, until the 1970s, for-profit colleges and universities were a miniscule part of the tertiary education universe. In 1967, for example, roughly 7 million students attended degree-granting institutions in the United States; and fewer than 22,000 of these students, or less than one-third of 1 percent, attended for-profit institutions.

By 2012, however, for-profit institutions in the United States have become 12 percent of the market. The same sorts of growth exist throughout the world. Malaysia, for example, has seen dramatic growth in the for-profit sector, as have other countries-such as, Turkey and Singapore. Three reasons account for that growth.

\section{For-Profit GROWTH}

First, educational entrepreneurs have seen an opening. John Sperling founded the University of Phoenix in 1976; Phoenix is now America's second-largest postsecondary institution, with over 400,000 students. Phoenix and other institutions began to experiment with the meaning and purpose of higher education in a number of ways. Part-time working adults have been viewed as a 
potentially huge customer base. These students do not need a campus and the related accoutrements-student centers, fancy eateries, and so on. Rather than a potpourri of courses whose utility for future work is not apparent, students select courses from a finite number that are offered at convenient times and locations. The focus is on efficiency. Faculty work is also very different. Tenure, shared governance, and academic freedom are largely absent. Whereas in traditional institutions the professor develops the syllabus-so that the same course might have different foci, objectives, and goals, depending on the instructor-at the for-profits, the syllabi are standardized. Pedagogy from class to class is more similar than different. Entrepreneurs have seen an opening in a "market" and they have taken it; and in doing so, they have redefined who the customer is and what the customer wants.

A second reason for the growth is due to the advances made in technology. Online learning is not yet optimal or pervasive, but we frequently forget how fast technology has been adopted throughout the world. The Web, the Internet, YouTube, and Facebook were unknown quantities, a little over a generation ago. The continued advances in technology have enabled courses to be reconfigured, in ways that were unthinkable when the University of Phoenix started. For-profit institutions have been early adopters of new technologies and, in doing so, have created new markets for themselves.

Finally, tertiary education is a growth industry. As importantly, the public sector cannot accommodate the vast postsecondary needs of the citizenry. Throughout the world the assumption is that more education is the way to economic growth. Public universities, traditionally configured, are unable to 
meet the capacity demands and the needs of traditionally aged students and working adults, without significant additions to their revenue streams.

\section{Challenges of Growth}

However, the explosion of growth in the for-profit sector has created related challenges. In particular, for-profits have been charged with unethical admissions practices, burdening students with an unacceptable level of debt, and not preparing students with the skills necessary for their wanted jobs. Because many students are the first family member to attend a tertiary institution, they may not understand the costs of attending a for-profit institution or the consequences of the loans obtained to pay for their training. Admissions counselors also may coerce potential customers with false advertising or promises of jobs that do not exist.

These issues are confusing because frequently students who attend forprofit institutions are also students who are most at risk of not completing their coursework. A country will want more students entering the postsecondary system, and those students are likely to come from populations with historically low participation and completion rates. Yet, those same students may not complete their studies at a level equivalent to traditional college-going populations, which means they will encumber loans on which they may default. Thus, how to determine acceptable levels of attrition, debt burden, and salaries upon completion are issues that are highly charged among critics and supporters of the for-profits.

The role of the government is to ensure that the citizenry is protected from fraudulent services. Just as the government watches over the health and food 
safety of its citizens, it must also put in place regulations to ensure that private companies perform in a manner that protects the customer. The simple suggestion is that the "buyer beware" is an unacceptable public policy, with regard to education. Education is a public good that not only benefits the individual but also the nation. Thus, a view to the future suggests that states will develop strategies to ensure that for-profit colleges and universities deliver highquality services, which not only benefit the customer but also aid the state in its quest for increased educational attainment for its citizenry. 